\title{
Study on the Integration Mode of Computer Network Technology and College English Curriculum
}

\author{
http://dx.doi.org/10.3991/ijet.v11i08.6046 \\ Zuhua Guo and Lixin Xu \\ Henan Institute of Technology, Xinxiang, Henan, China
}

\begin{abstract}
Teachers suffer from educating while students struggle with examination. College English teaching is too time-consuming and inefficient. These have been topics of concern and interest in the reform of college English teaching and learning in China. With the large expansion of the number of universities, the shortage of teaching resources has reached a bottleneck of the quality improvement of higher education in China. In the face of such a dilemma, the integration of computer network technology and curriculum teaching and the realization of the efficient integration of limited resources are an effective way to solve the pressing challenge. In this paper, the problems and advantages of the integrated mode of computer network technology and college English curriculum are discussed.
\end{abstract}

Index Terms-Computer Network technology; College English Curriculum; Integration; Evaluation

\section{INTRODUCTION}

Since the beginning of twenty-first century, information technology has been developing at an extraordinary pace. Among them, the development of computer network technology is the most striking. It not only changes the traditional teaching mode, but also impacts traditional teaching ideas, and even has changed the role and status of teachers and students in the traditional teaching process. This presents challenges to the traditional teaching method and the educational system of China [1]. In the current situation of College English teaching, spending too much time and low efficiency, indoctrination and inordinate concern about examinations are some of the problems troubling college English teaching. The shortage of foreign language teaching resources with the expansion of college enrollment has become a serious problem in college English teaching. In the face of this situation, the effective integration of computer network technology and college English curriculum teaching can be the key to solving these problems.

\section{RESEARCH ON THE INTEGRATION OF COMPUTER NeTWORK TECHNOLOGY AND COLLEGE ENGLISH CURRICULUM}

Since the beginning of this century, the use of computer information network has broken the traditional restrictions of time and place and formed a new open virtual and cross-border, cross-culture and cross-language space with information as the center, which provides a more convenient environment for the study of college English. The combination of college English teaching and computer network technology has attracted the attention of many

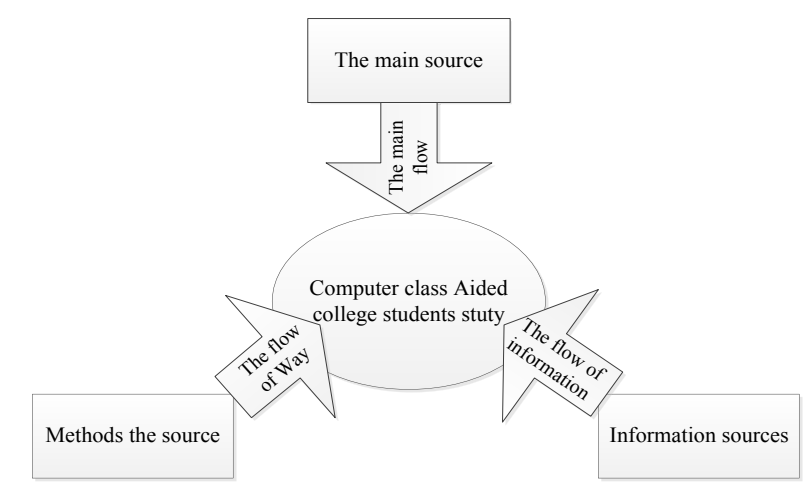

Figure 1. Computer aided students in colleges and universities English education

scholars globally. Cai Jing looks at college English teaching mode based on computer network platform from the two angles of teachers and students and proposes that college English teaching based on a computer network platform is a new mode of teaching and also the trend of modern education [10].

Constructivism education theory is the foundation of realizing the integration of multimedia network technology and English teaching. Information literacy of teachers and students is the prerequisite for the realization of integration. "Task based" English teaching is the core of the integration. Cui Shuzhen believes that modern network technology plays an important role in college English teaching [2]. The use of modern network technology in college English teaching has a variety of patterns. It should be guided by the constructivism theory and based on the improvement of network hardware and software. A breakthrough should be achieved from the reform of teaching methods and patterns. From looking at recent research, we know that most of the scholars have focused their attention on the aspect of the teaching mode and proposed the characteristics and advantages of the integration of computer network technology and multimedia teaching of college English. But there is no further research on the teaching mode. In this paper, combined with their own teaching experience, on the basis of referencing a large number of previous literature, the subject of the integration of the computer network technology college English curriculum is studied in depth. The method of integration is proposed from the construction of the integrated teaching mode of multi-angle and multi-level computer network technology and college English curriculum, giving the research a way to follow. At the same time, some lessons and problems are proposed, as shown in Figure 1. 


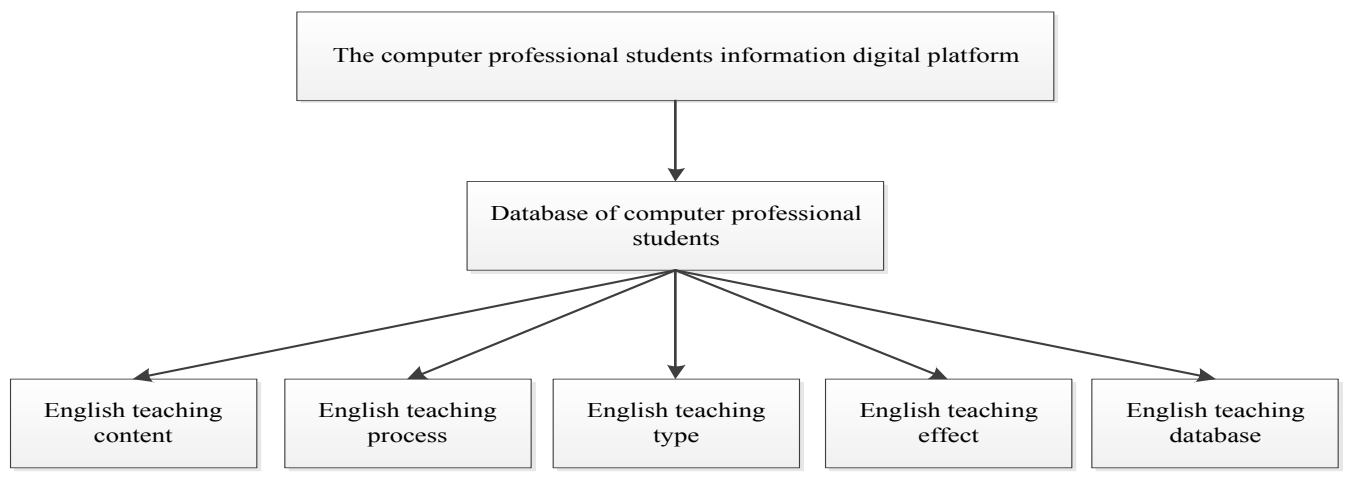

Figure 2. English teaching information framework establishment

\section{The AdVANTAgES Of THE INTEGRATION OF \\ COMPUTER NETWORK TECHNOLOGY AND COLlEGE ENGLISH CURRICULUM}

With the development of science and technology and the progress of the society, the computer network has been able to create a feasible multimedia teaching platform for college English teaching and provide the opportunity and means to reform the traditional teaching mode. The integration of computer network technology and college English curriculum has played an increasingly important role with its own advantages and has increasingly attracted the attention of teachers.

\section{A. Ability to play the main role of students}

The integration of computer network technology and college English curriculum is able to fully satisfy the needs of the students. Students can choose the most appropriate class time according to their own needs and possibilities and practice with the guidance of the computer as to provide the most appropriate teaching progress. In the face of difficulties, they could slow down the pace of learning and require added explanations or increase the amount of exercises as shown in Figure 2. When the students feel relaxed, after being tested by a computer and passing the test, they could speed up the progress, or reduce the amount of exercise according to their progress. In this process, students could consolidate the correct language skills, correct mistakes in the learning process and form more beneficial language habits. Students can also call a variety of courseware or materials at any time, or query, access and download a variety of information sources of teaching websites, carry out individualized learning and request for teachers' counseling and answering questions via email. This kind of students' interference free learning can allow students to understand their own learning situation in a timely manner and maximize the students' learning initiative, generating motivation to learn English [3]. At the same time, due to the multimedia interactive learning environment, illustrated, combination of static with dynamic, sound fused with intelligence, the use of audio and vision and realistic performance, learning can be more like a game, which is able to develop students' non-intellectual factors, and mobilize students' learning potential and greatly improve the effect of learning.

\section{B. Ability to stimulate students' interest in learning}

In addition to the traditional textbooks, teachers can call for a variety of data to edit and make a teaching courseware which conforms to their own teaching style and meet the different needs of students according to each student's situation. They could also search and select learning materials online to constantly enrich and renew the teaching content. For example, in the reading class, they could replace part of the contents with new materials under the premise of not changing the language learning requirements of the course, making the curriculum having an historical accumulation, and the characteristic of the times. It stimulates students' learning interest and initiative and achieves the teaching objectives, which solves the problems of little capacity of materials and old contents as shown in Table 1 and Figure 3.

As the international language of the Internet is English, there are many resources stored in the form of multimedia online. There are topical newspaper resources, entertainment resources of astronomy, geography, culture and education and even specialized teaching resources [4]. These resources provide students with authentic information without any processing. This kind of foreign language learning with rich information is a natural approach of second language teaching and learning, as linguist Kristen advocates as a mass input and natural acquisition and makes use of real language to complete the task of real communication.

TABLE I.

IMPROVING THE LEVEL OF BASIC COMPUTER ENGLISH EDUCATION MEASURES

\begin{tabular}{|l|l|l|}
\hline Number & Method & Percent \\
\hline 1 & Leadership attaches & 34 \\
\hline 2 & Teachers troop & 38 \\
\hline 3 & Improve conditions & 26 \\
\hline 4 & Teaching methods & 34 \\
\hline 5 & Construction of teaching material & 24 \\
\hline 6 & Education technology & 25 \\
\hline 7 & Curriculum reform & 38 \\
\hline 8 & Professional support & 16 \\
\hline 9 & Others & 4 \\
\hline
\end{tabular}




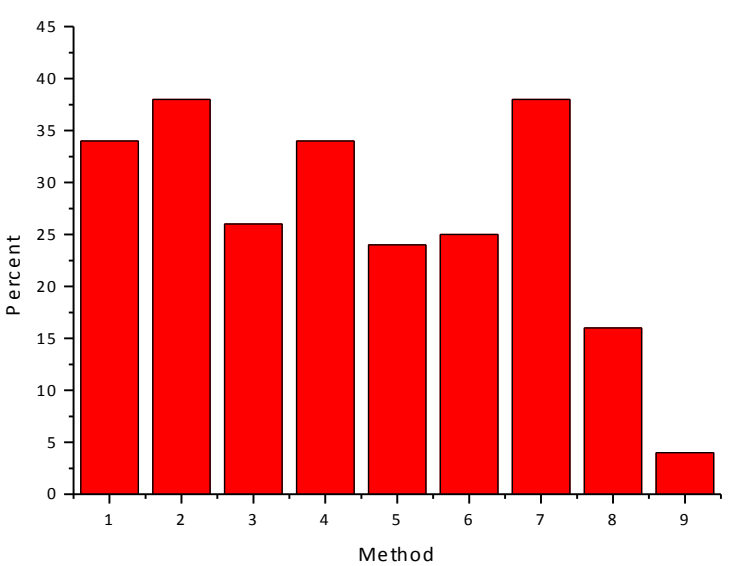

Figure 3. Improve the level of basic computer education measures

\section{Ability to provide scientific evaluation criteria}

The integration of computer network technology and college English curriculum provides a scientific evaluation standard for teaching and learning. In using the computer network system for language teaching, teachers can design and develop a variety of scientific testing methods, track, record and analyze students' understanding and make a scientific and reasonable evaluation of the results of teaching. For example, teachers can design forms of testing and practice such as self-testing, special exercises, stage test, comprehensive review questions and quiz, etc. on the computer and then put the exercises together with the answers on the Internet. Students can choose the time to test according to their own learning progress. Teachers can analyze the results of teaching according to the answers and feedback from students, and adjust the teaching schedule, teaching content, teaching plan, and so on. Students can also use the advantages of multimedia network teaching, choose the appropriate learning tasks according to their own cognitive characteristics and interests and hobbies, and receive timely feedback to analyze and evaluate their own learning progress at any time. Therefore computer network technology provides an approach of rapid, timely and accurate feedback of information, and provides a communication platform for teachers and students with a scientific evaluation standard for teaching and learning that greatly optimizes the English teaching means and promotes the improvement of teaching quality.

\section{RESEARCH ON THE INTEGRATION MODE OF COMPUTER Network TeChNOLOGY AND COLLEGE ENGLISH CURriculum}

\section{A. Teaching mode of the integration of computer network technology and college English curriculum}

From the perspective of information transmission, teaching is a two-way or multi-directional dynamic process for teachers to transfer information to students. Computer network technology is a carrier of information of teachers, and it is also the source channel for students to acquire knowledge and obtain information. Teachers should make use of the advantages of computer network technology in teaching, develop practical and feasible mode to make the computer network technology and college English teaching integrated organically, making teachers, the computer network technology and students effectively unified and improving the quality and results of teaching.
(1) Classroom teaching mode

In the integration process, teachers can choose a working platform to prepare lessons, making full use of the various multi-media teaching resources on the Internet to create new courseware to adapt to their own teaching characteristics. New courseware is designed based on the existing courseware templates and multimedia material in the resource library. This design method is simple and easy to learn [5]. Furthermore, the existing teaching courseware in the resource library can be selected and inserted into the current directory in the teaching resource database together with the new courseware. The system administrator establishes a personal directory for each teacher in the resource library of college English teaching. In class, the teacher simply needs a multimedia computer connected to the campus network, a projector and a screen to directly call the prepared courseware under their own catalogue of college English resource bank and offer these resources to classes according to their intention. The greatest advantage of this mode is that it can combine the traditional teaching method with modern multimedia computer assisted instruction. Teachers can directly communicate with students or through the computer. Teachers can get feedback from students in a timely manner when teaching language knowledge and skills to students and flexibly adjust the teaching method and the progress, making the design of the new courseware more in line with the actual situation of the students. Some teaching contents which are not easy to be expressed by traditional teaching can be presented visually by the network multimedia computer, making the classroom lively, and arousing the students' enthusiasm and interest in learning and deepening students' understanding, memory, and mastery of language.

(2) Network collaborative learning mode

In the integration process of computer technology and college English curriculum, students can form a group in a dormitory and use the existing multimedia computers, campus network and college English resource library of the dormitory to study and discuss the contents specified by teachers. The class could also be divided into several groups randomly in the college English multimedia laboratory in the school. The group size could be large or small and it could be two, three, four to eight etc. The members of the group could call the college English teaching resources, propose their own problems in the study and ask the other members of the group to help solve the problems [6]. If the team members cannot solve the problem, they can ask the teacher to help, or ask other team members to help. In this mode, they can learn with discussion and the team members can express their understanding of course contents when calling the courseware of the college English teaching resources in the library for learning. The collaborative learning mode can improve the ability of students to solve their problems on their own, enhance their confidence and interest in learning knowledge and enhance their sense of unity and cooperation, as shown in Figure 4.

(3) Electronic network interaction mode

Teaching is a process of information exchange between teachers and students. The computer network technology provides the hardware and the technical support for the realization of the interaction in English teaching. In the 


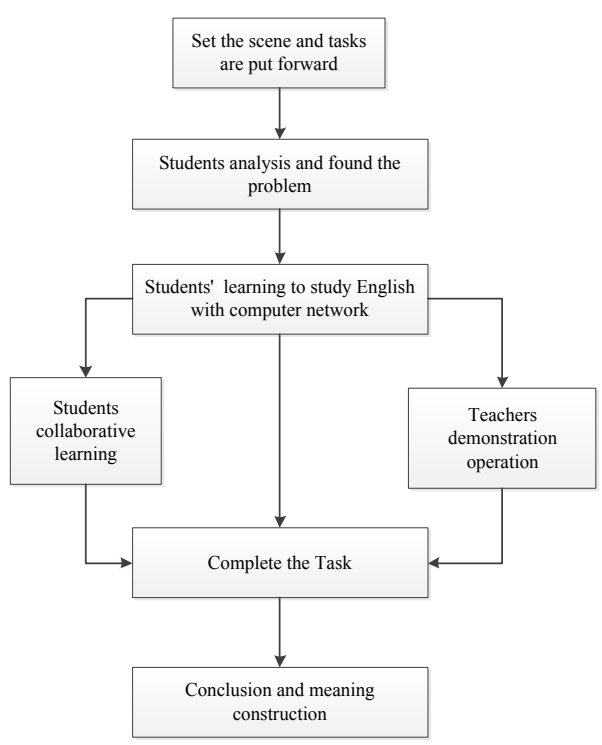

Figure 4. Students learning English modes

teaching practice, teachers should make use of the advantages of computer network technology to develop the interactive teaching mode supported by electronic equipment [7]. The computer network technology is used to provide various forms of language practice opportunities for students to make them communicate using English in the forms of human-computer interaction, teacher-student interaction and student-student interaction, to improve the language application ability and oral expression capability. In the one-way communication of human-computer interaction, students can access a website, search the required English information, and widen the knowledge of English learning. In two-way and multi-electronic communication of teacher-student interaction and student-student interaction, students can freely communicate with fewer concerns and less mental stress and can also talk to English learners and users around the world through the Internet. In this way, students can contact the linguistic knowledge and cultural information in a multi-dimensional and multiangle way and carry out the interactive communication through the two-way communication between individuals or multi-directional communication in groups, cultivating and improving the capability of language communication [9].

\section{B. Teaching structure of the courses}

The teaching structure of the courses should be reformed first if the teaching model is to be reformed. The necessity of the structure "basic English + industrial English" adopted in the public English education in vocational schools has been described by some experts of "English Teaching and Instruction Committee". The key of the reform is that English teaching should be integrated by the modern information and technology which is centered on computer network technology based on the current structure "basic English + industrial English". Furthermore, it should be integrated in every linage of the public English education in vocational schools. Referring to graph one, we are able to determine that in the new model, the course-teaching structure "basic English + industrial English" is the core in the whole process of English teaching. The purpose of studying the "basic English" is to connect with the English knowledge of high school and enhance the comprehensive ability of listening, speaking, reading and writing so as to prepare for the industrial English study in the next stage. The purpose is also to prepare for the examinations of CET-3 and College English Practical Proficiency-Test B which are stipulated by the teaching program, as shown in Figure 5.

\section{Teaching process}

Teaching process consists of five linkages:

(1) Hierarchical test: For the first week when the freshman of the vocational school are recruited, they are required to take part in a hierarchical test of public test, after which, the test will be submitted to the system which makes automatic feedback and evaluation with the corresponding model and level of English being recommended to students.

(2) Screening courses in network: The students will choose a level, model, teachers and complete the registration. The system will then generate an account and password correspondingly so as to establish electronic learning archives.

(3) Proceeding with study of consistent level: Students are able to preview a course in advance and carry out study of extra-curriculum according to their needs by adopting "network autonomous learning system".

(4) Taking part in course study in classrooms: PPT will be adopted to directly show the courses information and encourage students to engage in a simulated learning situation of vacation English. In this way, students are also willing to take part in activities through various classroom and discussion problems by adopting the network, etc. The classroom interactive activities generated by the computer network technology are divided into six steps:

Stage 1: At the beginning of classes, teachers will introduce the content of courses to be delivered by PPT. Students will listen which is generally a one-way activity;

Stage 2: Teachers will instruct and invite students to interact and discuss with them by means of questions and answers, which is open and a two-way discussion is carried out by teachers and all the students in which the tasks are distributed to every student and the ways for discussion are consulted and negotiated among them as well.

Stage 3: This is the one-way teaching process similar to Stage 1 in which the teachers will explain the rules for the group activity.

Stage 4: This is the group discussion in which students interact and discuss with each other in groups freely formed or sorted by teachers so as to independently complete the tasks.

Stage 5: This is the group report and presentation. Stage6: This is the comments and feedback from the teachers and the summary. Obviously, the computer network technology will provide opportunities for students to participate in social activities and establish the meaning of targeted language in a real vacation context, which is conducive to stimulating learning motivation and interests.

(5) Evaluation and test

The formative assessment includes the frequency and quality of discussion on the Internet, including activities, homework, and feedback of enterprises where the students has interned, recording of the learning process and so on. Summative assessment refers to the comprehensive evaluation of language ability with practical evaluation being the major content. 


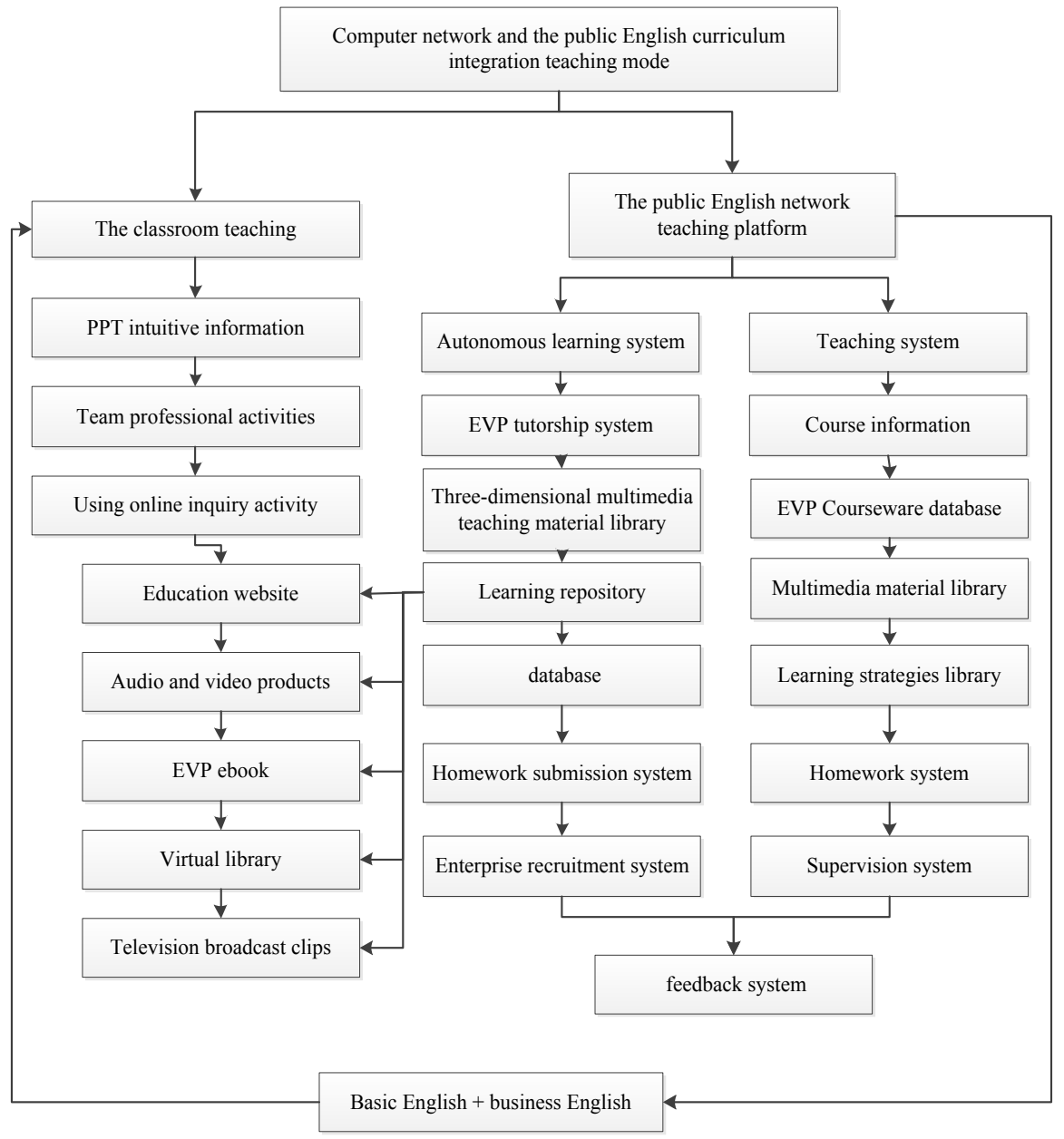

Figure 5. The computer network course in English

D. The advantages of the integration of computer network technology and college English curriculum

(1) To break limitations of traditional classroom teaching.

Computer assisted instruction is actually based on a combination of classroom and textbook, which means that the textbook is the only source of students' knowledge. Textbook based teaching means that the relationship between teachers, textbooks and students is that teachers dominate the classroom interaction and transfer knowledge to students through the use, analysis and explanation of the information contained in the textbooks. Textbooks are just a medium of communication between teachers and students. Students learn, passively receive knowledge from the textbook through the analysis and interpretation of teachers.

(2) To open the traditional teaching and learning environment.

The integration of computer network and college English curriculum is conducive to changing and opening the traditional teaching and learning environment, thus creating an ideal teaching environment. The creation of this ideal environment benefits from the rapid development of computer network technology. The use of a computer network has three major technological advantages of artificial intelligence, digital and network technology, providing the possibility for the creation of the ideal environment for college English teaching. The ideal learning environment includes scene based learning, cooperative learning and open learning.

(3) Changing the traditional teaching structure.

The integration of computer network and college English curriculum can create an ideal teaching environment, and can also change the teaching structure system fundamentally. The traditional teaching structure using "teaching" as the center is changed into the teaching structure of "learning and teaching"; i.e., the teaching structure of teacher-led and students as the main body. $\square$ The leading role of teachers. In the structure of teaching, teachers should have a new understanding of the change of the teaching structure in order to change their traditional methods. With the teaching experience of computer and curriculum integration, teachers can use the advantages of the computer to design and create a learning environment for the integration of curriculum combined with the learning characteristics of students. $\square$ The main role of students. First of all, students will be more actively involved in learning activities. Secondly, students will take on the role of the researcher; Finally, students will naturally want to become a skilled operator of computer technology.

\section{CONCLusions}

The subject group has begun to research the network teaching of public English in vacation school since 2009. Since 2011, the subject group has tried to implement the teaching model which integrates the computer network technology and public English in vacation school by 
PAPER

Study ON THE INTEGRATION MOdE OF COMPUTER NETWORK TECHNOLOGY AND COLLEGE ENGLiSH CURRICULUM

drawing lessons from the concept of the Virtual University in Michigan and the teaching experience of network language teaching of the author in America so as to gradually develop and research the teaching platform. Currently, the campus network version has been completed, but portions of the resources base and systems still need to be improved. The system has been in trial use for one semester in "basic English stage" of ESP courses of Architectural Design Technology major in national demonstrative vacation school (cooperated by China and Australia). What is more, it will gradually be transited to "industrial English" by integrating "vacation English". There were 87 freshmen recruited in this major in 2012. After the hierarchical test, adopting the testing paper whose difficulty coefficient is equivalent to the Test B of College English Application Ability, the number of students in A class is 44; the number of students in B class is 43. According to the willingness of students, the small classes of "network English model" and the comparative classes of the "traditional model"are compared. In the process of teaching, the experimental class adopts the new model and uses the "the network teaching platform of public English in vacation school". The teachers include two English teachers with one teacher of architectural design major. They collectively prepare classes, make classes material and establish teaching platform. The teaching methods are in accordance with ESP and CB $\square$ methods. The traditional teaching model is adopted by the comparative group. In five months, class observation, semi-controlled students interview, learning diary, group activity recording or video methods are adopted for collecting data in the process.

(1) In the final examination in January of 2013, the oral English test was conducted in the form where students were divided into 3-5 people in a group. Then they studied the preset problems by searching information on the Internet, collectively completing the PPT for vacation scenes and then the group members made presentation in a roleplaying format. This kind of test takes $50 \%$ of the whole test. The paper test adopts the testing paper whose difficulty coefficient is equivalent to the Test B of College English Application Ability. This kind of test comprises $50 \%$ of the whole test. From comparison and analysis, it is revealed that the scoring of students in the paper exam taught by "network English model" is clearly better than that of the students taught by the "traditional method" with an average score in the paper being 8 points higher. In terms of the oral exam, the students in the experimental class were more confident, and more willing to speak in front of teachers and students, which also stimulates them to make better and full preparation and makes them communicate with students more frequently. In this way, the language input is better; the quality of construction significance is higher, so the score of oral test is also higher. In the questionnaire of the end of the semester, $93.2 \%$ of the experimental class thinks that "they are more willing to study in the multiple-media network environment compared to the traditional classes". $72.9 \%$ of the students think that "I have improved abilities in various aspects in the environment of network professional English study". $82.6 \%$ of the students choose that "I am interested and confident for the studying plan and model which vary according to personal situation". $45.7 \%$ of the students choose that "I love the way in which teachers use email and chatting to instruct and supervise my study". $89.9 \%$ of the students are "much willing to study English in this model, because this is so conductive for future jobseeking". These conclusions are consistent with the results obtained from the analysis of the data and material which were collected by various ways in the teaching process.

(2) The English basis of listening, speaking, reading and writing of vacation school students is weak and they are not so much motivated for study. The autonomous learning environment based on the computer network has provided personalized learning platform, has stimulated their learning interests and encouraged their spirits. Obviously, the combination model of computer network and public English in vacation school is conducive for cultivating the learning custom and ability of students in vacation school so as to improve the teaching effectiveness.

(3) The integration of computer network technology and college English teaching is the development direction of modern foreign language education, and it is the inevitable trend of college English teaching reform. Computer network English teaching has many advantages compared with the traditional teaching mode, which provides an ideal language teaching environment for the implementation of quality English education, and is helpful to improve students' comprehensive ability and comprehensive quality, cultivate students' autonomous learning capabilities and play a main role for students in the teaching process. As practitioners of teaching, English teachers should ideas adapt their way of thinking, innovate boldly, study the theory and application of computer network technology in depth, learn the theory of modern foreign language teaching, explore the teaching rules and teaching mode of computer network. In this way, educators can seek the best integration of computer network technology and college English teaching, optimize the teaching means, improve the quality of teaching and cultivate high-quality personnel with strong English ability.

\section{REFERENCES}

[1] L. Chen, "The research on the effects of Computer Assisted Language Learning on English teaching. 2012 2nd International Conference on Consumer Electronics," Communications and Networks, CECNet 2012-Proceedings, pp. 3631-3633.

[2] X.Y. Chen, "Application of Computer Aided Instruction (CAI) in English teaching for non-English-major postgraduates based on constructivism," Advances in Intelligent and Soft Computing, Vol. 140, pp. 205-210. May 2012. http://dx.doi.org/10.1007/978-3-64227945-4 32

[3] Y. Chen, "The application of multimedia computer assisted language learning in English teaching," Advanced Materials Research, Vol. 926, pp. 4634-4637, March 2014. http://dx.doi.org/10.4028/www.scientific.net/amr.926-930.4634

[4] H.Y. Gao, "Integrated application of computer technology in English teaching," WIT Transactions on Engineering Sciences, Vol. 87, pp. 911-916, June 2014. http://dx.doi.org/10.2495/ AMITP131091

[5] Y. Liang, T.T. Zheng, "Computer-assisted college English teaching under the perspective of "embodied philosophy"," 2011 International Conference on Multimedia Technology, ICMT 2011, pp. 3005-3007. http://dx.doi.org/10.1109/ICMT.2011.6003095

[6] S. Li, "Multimedia computer assisted instruction in college English teaching," Proceedings-4th International Conference on Computational and Information Sciences, ICCIS 2012, pp. 754757.

[7] B. Shi, "Empirical research on feasibility and effect of computeraided College English teaching model," Proceedings-2009 International Conference on Information Engineering and Computer Science, ICIECS 2009, pp. 236-241. http://dx.doi.org/10.1109/ iciecs.2009.5362868 
PAPER

[8] Y. Wang, Y. Bao, "Research on human-computer interaction of English teaching at local area network," ICCASM 2010 - 2010 International Conference on Computer Application and System Modeling, ICCASM 2010, Vol. 7, pp. 2718-2722. http://dx.doi.org/10.1109/iccasm.2010.5620224

[9] Q.H. Yang, "Research of college English teaching based on computer network technology, Lecture Notes in Electrical Engineering, Vol. 206, pp. 375-382, April 2013. http://dx.doi.org/10.1007/ 978-1-4471-4790-9 48

[10] X. Wu, H. Chen, "Computer-based educational game and its application in college English teaching in China," 2011 International Conference on Multimedia Technology, ICMT 2011, pp. 3008-3011.

[11] X.H. Chen, "The research on English autonomous learning monitoring theory and application in the network environment," $\mathrm{Ap}$ plied Mechanics and Materials, vol.12, pp.6079-6082, March 2014. http://dx.doi.org/10.4028/www.scientific.net/AMM.644650.6079

[12] S.F. Han, S. Miaomiao, "On college English teaching of writing in the network environment," 2011 International Conference on Multimedia Technology, ICMT 2011, pp.588-590. http://dx.doi.org/10.1109/ICMT.2011.6002176

[13] S. Lixia, "Survey research on college students' English learning anxiety in the computer network environment," ICCSE 2011-6th International Conference on Computer Science and Education, vol.36, pp.1010-1012, June 2011. http://dx.doi.org/10.1109/ iccse.2011.6028807

[14] J. Song, "The English teaching model of cooperative learning in the network environment in higher vocational education," Communications in Computer and Information Science, vol.218, pp.100-104, March 2011. http://dx.doi.org/10.1007/978-3-64223357-9_19

[15] Q.L. Sun, "Information under the network environment using computer information security technology. Proceedings-2015 International Conference on Intelligent Transportation, ICITBS 2015, pp.474-477.

[16] X.H. Chen, "The research on English autonomous learning monitoring theory and application in the network environment," $A p$ plied Mechanics and Materials, vol. 12, pp. 6079-6082, August 2011.

[17] S.F.Han, Miaomiao, S. "On college English teaching of writing in the network environment," 2011 International Conference on Multimedia Technology, ICMT 2011, pp. 588-590. http://dx.doi.org/10.1109/ICMT.2011.6002176
[18] S. Lixia, "Survey research on college students' English learning anxiety in the computer network environment," ICCSE 2011-6th International Conference on Computer Science and Education, vol. 36, pp. 1010-1012. May 2011. http://dx.doi.org/10.1109/ iccse.2011.6028807

[19] J. Song, "The English teaching model of cooperative learning in the network environment in higher vocational education," Communications in Computer and Information Science, vol. 218, pp. 100-104, August 2012. http://dx.doi.org/10.1007/978-3-64223357-9 19

[20] Q.L. Sun, "Information under the network environment using computer information security technology," Proceedings-2015 International Conference on Intelligent Transportation, ICITBS 2015, pp. 474-477. http://dx.doi.org/10.1109/icitbs.2015.122

[21] M.Q. Xu, "The research on out-of-class autonomous English learning in computer-and network-assisted environment," Advances in Intelligent and Soft Computing, vol. 36, pp. 453-459. August 2011. http://dx.doi.org/10.1007/978-3-642-24775-0 71

[22] D.L. Yang, H. Zheng, "Research on the framework of new college English teaching mode integrating cooperative and autonomous learning in the network multimedia environment," ICETC 20102010 2nd International Conference on Education Technology and Computer, vol. 3, pp. 3256-3259, April 2010

\section{AUTHORS}

Zuhua Guo is an associate professor. She works in department of Computer Science and Technology, Henan Institute of Technology. His research direction is Computer Network Technology (e-mail: 33374035@qq.com).

Lixin $\mathbf{X u}$ is a professor. He works in department of Computer Science and Technology, Henan Institute of Technology. His research direction is Computer Network Technology (e-mail: xulixinls@163.com).

This paper is supported by Project Name: Science and technology key research projects in henan province department of education, Project Number:13A520221 and 14A520045; Project Name: National 863 high technology research and development program funded projects, Project Number:2013AA01A215; Project Name: Provincial teaching reform project in henan province department of education, Project Number: 2014SJGLX402. Submitted 16 July 2016. Published as resubmitted by the authors 23 August 2016. 